\title{
FILOZOFIA RELIGII A FILOZOFIA BOGA I METAFIZYKA
}

Tytuł artykułu wyznacza dość wąski temat rozważań z zakresu problematyki teoriopoznawczo-metodologicznej. Oczekuje się próby określenia statusu metodologicznego przede wszystkim filozofii religii i wskazania na jej związki z filozofią Boga i metafizyką. Zadanie jest pozornie łatwe. Istnieje bowiem wiele sposobów uprawiania każdej z wyżej wymienionych dyscyplin i wobec tego różne zachodzą między nimi relacje. Trudno przedstawić wszystkie możliwe ujęcia i układy, z góry trzeba więc zaznaczyć, że będzie to ujęcie fragmentaryczne. Podejmując próbę określenia filozoficznej wiedzy o Bogu i religii, wydaje się niezbędne - chociaż skrótowe - nakreślenie współczesnej sytuacji myślowej w zakresie wiedzy o religii. Stanowić to będzie pewne tło dla zdania sobie sprawy, jakie problemy wysuwają się na plan pierwszy i jaki typ filozofii może te problemy podjąć.

Ostatnie stulecie - to czas wzmożonego negatywnego i pozytywnego zainteresowania religią. Jest to bowiem okres wielkich negacji religii dokonywanych przez znaczące XIX i XX-wieczne prądy i ideologie, czas „uśmiercania Boga" w imię czlowieka,

- by osiągnął stan całkowitego spełnienia („raj na ziemi”), zbawił sam siebie przez rewolucyjne tworzenie nowych struktur ekonomiczno-spolecznych (K. Marks)

- by był całkowicie samodzielny i dojrzały (F. Nietzsche)

- by był absolutnie wolny (S. Freud, J. P. Sartre).

Dziś już z doświadczenia wiemy, do czego doprowadziły próby, dokonywane różnymi środkami — nie wyłączając politycznych — eliminacji religii zludzkiego życia i z ludzkiej kultury. Wiele pisze się i mówi o zniewoleniu człowieka, o utracie przez wielu sensu życia, o nowych formach alienacji, o dehumanizacji człowieka pozbawionego transcendentnych perspektyw i wartości.

* Poniższy tekst jest przeredagowaną wersją wykładu wygłoszonego podczas sympozjum Z problematyki wspótczesnej filozofii religii, 18 XI 1988, w Papieskiej Akademii Teologicznej w Krakowie. 
Wiek XX — to równocześnie okres dynamicznego i efektywnego rozwoju różnorodnych badań nad religią, prowadzonych przy pomocy różnych metod, rozwój wiedzy humanistycznej, a więc etnologii, historii, psychologii, socjologii religii, a nade wszystko fenomenologii religii w jej różnych wariantach. Tej, która na bazie doświadczenia historycznego (M. Eliade, van der Leeuw) czy psychologicznego (R. Otto) ustalała stałe struktury i przejawy życia religijnego. Byłaby to fenomenologia humanistyczna oraz fenomenologia filozoficzna uprawiana w ramach fenomenologii jako nurtu ściśle filozoficznego z jej twórcą M. Schelerem na czele. Dzięki fenomenologii został ukazany istotny związek fenomenu religii ze świadomością ludzką, ludzkimi dziejami i ludzką kultu$\mathrm{rą}^{1}$.

Spoglądając na wiek XX z punktu widzenia stosunku do religii zarysowują się wyraźne różnice między jego początkiem i końcem. O ile w pierwszym okresie dominował zdecydowanie negatywny stosunek do religii i proklamowany ateizm mial charakter prometejski, to obecnie obserwujemy inne nastawienie do religii nawet na terenach i w ideologiach, w których walka $\mathrm{z}$ religią była zdecydowana i konsekwentna. Socjologowie kultury (Bell) mówią o powrocie sacrum w końcu XX wieku. M. Eliade, wielki badacz i teoretyk religii, twierdzi, że największym osiągnięciem XX wieku nie są odkrycia naukowe ani nawet rewolucyjne przemiany społeczne, lecz powtórne odkrycie podstawowego znaczenia sacrum dla ludzkiego życia² .

Rodzi się więc pytanie, jak wytłumaczyć ów powrót. Skąd się bierze owa intrygująca trwałość myśli o Bogu i religii, mimo jej nieustannego zwalczania? Ani wiedza humanistyczna, ani fenomenologia, ani hermeneutyka języka religijnego czy inne „myślenie o kulturze” tego problemu nie rozstrzygną ${ }^{3}$.

W tej ogólnokulturowej i myślowej sytuacji zastanawiająca jest sytuacja w Polsce. W okresie dysponowania rozległą wiedzą o religii, wykazującą jej ścisły związek z ludzką świadomością i kulturą, w okresie powrotu sacrum nawet w Związku Radzieckim, w Polsce wprowadza się religioznawstwo marksistowskie, które ukazuje religię jako dehumanizującą człowieka alienację, uwarunkowaną czynnikami społeczno-ekonomicznymi. Religioznawstwo nadal głosi ateizm i zdania o nieistnieniu Boga uważa za twierdzenie naukowe ${ }^{4}$.

Mimo więc olbrzymiej wiedzy penetrującej świadomość religijną czy analizującą religijną mowę (język religijny), mimo przyjęcia religii jako stałego ele-

${ }^{1}$ Por. Z. J. Zd y bicka, Religia i religioznawstwo, Lublin 1988, zwłaszcza rozdział: Problematyka nauk o religii, s. 319-348; G. L a n czk ow ski, Wprowadzenie do religioznawstwa, tł. A. Bronk, Warszawa 1986; A. B ronk, Postowie: Możliwości i ograniczenie religioznawstwa, tamże, s. $130-148$.

${ }^{2}$ M. Elia de, Historia wierzeń $i$ idei religijnych, t. 1, przeł. S. Tokarski, Warszawa 1988, zwłaszcza słowo od wydawcy, s. VI.

${ }^{3}$ Zagadnienie to szeroko omawia E. Gils on w: L'atheisme difficile, Paris 1979.

${ }^{4}$ Por. Z. Kawecki, W. Tyloch, Wybrane problemy religioznawstwa, Warszawa 1987, oraz hasło ateizm w: Leksykon religioznawcy, Warszawa 1988, s. 15-23. 
mentu kultury, w dziedzinie wiedzy o religii, zwłaszcza jej podstawach oraz wiedzy o istnieniu Boga wciąż jesteśmy jakby „na początku”. Trzeba więc sięgać po prawdy fundamentalne, podstawowe, na które tak silny nacisk kładzie właśnie filozofia w jej rozumieniu klasycznym.

Czym jest religia — alienacją, złudzeniem, neurozą, przejściowym etapem ludzkości czy sposobem istnienia człowieka? Jakie są jej źródła, geneza, dlaczego istniała i nadal istnieje? Jakie pełni funkcje w życiu ludzkim — jednostkowym i społecznym, w ludzkiej kulturze?

Czym jest sacrum — korelatem ludzkiej świadomości, rzeczywistością kulturową, intencjonalnym przedmiotem aktu religijnego czy żywą, realnie istniejącą osobą, z którą jesteśmy związani?

Pytania, tak istotne dla zrozumienia, czym jest religia, także obecnie nie są pytaniami retorycznymi. Właśnie te pytania i realne współczesne problemy skłaniają nas do zajęcia się filozofią religii oraz jej stotunkiem do filozofii Boga i metafizyki i wskazania na takie ujęcia, które podejmują te fundamentalne problemy.

\section{RÓŻNORODNOŚĆ SPOSOBÓW UPRAWIANIA FILOZOFII BOGA I FILOZOFII RELIGII}

Historycznie i współcześnie istnieje wiele sposobów uprawiania filozofii w ogóle a w konsekwencji istnieje pluralizm typów wiedzy o całej rzeczywistości, Bogu i religii ${ }^{5}$. Najtrudniejszy do określenia jest status filozofii Boga. Jeśli w filozofii rozpoczynamy od analizy danych w doświadczeniu faktów, to przecież Bóg nie jest wprost dostępny naszemu poznaniu, wobec tego nie może być punktem wyjścia odrębnej dyscypliny filozoficznej. Ten typ wiedzy ma zawsze postać dość skomplikowaną. Przypatrzmy się konkretnym sposobom jej uprawiania czy wykładania, zwłaszcza w instytutach kościelnych.

\section{Filozofia Boga ściśle zwiazana z metafizyka}

Problematyka istnienia Absolutu (Boga) pojawia się w metafizyce czyli ogólnej teorii bytu. Skoro różne byty, dane w poznaniu bezpośrednim, w analizie okazują się niekonieczne, bytowo niewystarczalne, zmienne, jawi się problem ich ostatecznego źródła istnienia. Problematyka Boga stanowi integralną część metafizyki, Jeśli wykłada się je oddzielnie, to po prostu jest to fragment metafizyki naświetlający ostateczne uwarunkowania istniejącej rzeczywistości.

${ }^{5}$ Por. Z. J. Zdy bicka, Człowiek i religia, Lublin 1977 (1980). 
Wiedza metafizyczna o Bogu może być dopełniana i modyfikowana na różne sposoby, zawsze zachowując perspektywę metafizyczną, doszukującą się ostatecznych uwarunkowań dla istniejącej rzeczywistości czy to bytów w ogóle, czy jakiejś dziedziny rzeczywistości człowieka, moralności itp.

\section{Filozofia Boga niezależna od metafizyki}

Filozofia Boga może być uprawiana niezależnie od metafizyki, zwłaszcza jako wyrażenie i eksplikacja ludzkich doświadczeń i przeżyć w perspektywie Transcendensu (G. Marcel, M. Buber). Może być także metodologicznie złożona jako zespół problemów należących do różnych dyscyplin filozoficznych — metafizyki, antropologii, filozofii moralności, filozofii religii - wydobywa się z tych dyscyplin problematykę wprost związaną z zagadnieniem Boga. Istnieje filozofia Boga będąca syntezą filozoficznej i teologicznej wizji świata. Są to postacie filozofii chrześcijańskich, np. św. Augustyna. Istnieje postać filozofii Boga, którą można określić jako scjentystyczną, gdzie zwykle nie wyklucza się całkowicie metafizyki, skupia się jednak refleksję na problemach będących na styku nauk przyrodniczych, humanistycznych, psychologii, socjologii, itp. Zawsze wiodące jest filozoficzne pytanie o podstawy, źródła ostateczne, początek rzeczywistości, będącej przedmiotem badań w poszczególnych naukach szczegółowych.

\section{Filozofia religii}

Status filozofii religii jest łatwiejszy do określenia niż status filozofii Boga. Występuje tu bowiem wyraźnie przedmiot dany do badania. Jest nim dany w doświadczeniu wewnętrznym (u ludzi religijnych) i w doświadczeniu zewnętrznym fakt religijny. Zadaniem filozofii religii jest opis tego faktu, jego interpretacja i wyjaśnienie. Filozofia religii może przybierać różną formę w zależności od kontekstu filozoficznego, w którym jest uprawiana, od rozłożenia akcentów na poszczególne etapy refleksji. Może więc mieć charakter bardziej opisowy, bardziej interpretacyjny czy wyjaśniający.

Opisowa filozofia religii jest analizą i opisem ujętego intelektualno-intuicyjnie fenomenu religii w jego pierwotności i istocie (jako coś danego w świadomości). Stosuje się tu szeroko rozumianą metodę fenomenologiczną, w wyniku której otrzymuje się szczegółowe opisy aktów religijnych, ich przebiegu, istoty boskości, sacrum itp. Inną postacią filozofii jest szczegółowy opis ujętego za pomocą specjalnej intuicji pozaracjonalnej przeżycia religijnego. Suponuje się swoiste „odczucie” (Gefühl-sacrum) (F. Schleiermacher, James, R. Otto). 
Interpretacyjne filozofie religii; można tu zaliczyć hermeneutyczną filozofię religii w ujęciu P. Ricoeura - rozumianą jako interpretacja czyli wydobycie głębszego sensu i jego uwarunkowań religii potraktowanej jako system symboli występujących w określonym kontekście. Tutaj trzeba zaliczyć filozofię religii rozwijaną w ramach filozofii analitycznej, która odsłania funkcjonowanie języka religijnego i tą drogą zdobywa wgląd w fenomen religijny (Ramsey).

Wyjaśniające filozofie religii - po opisie i interpretacji skupiają się na wyjaśnianiu ostatecznym, wskazują na ostateczne uwarunkowania religii bądź przy zastosowaniu metody metafizycznej, bądź przez zastosowanie metody transcendentalnej. Filozofia religii stanowi wówczas refleksję zmierzającą do wskazania koniecznych, podmiotowych warunków zachowania się człowieka, w tym przypadku zachowania religijnego (J. B. Lotz).

Filozofia religii może być uprawiana w sposób bardziej kompleksowy, wręcz - eklektyczny. Może przybierać różne formy, czy to refleksji przebiegającej na styku metafizyki, filozofii Boga, antropologii filozoficznej i aksjologii czy łączyć różne kierunki filozoficzne gromadząc wiedzę i refleksję dotyczącą religii jako relacji między człowiekiem i Bogiem.

Filozofia religii może być powiązana $\mathrm{z}$ apologetyką czy przybierać jej postać, stanowiąc krytyczną analizę wiarygodności konkretnej religii objawionej.

Przytoczona skrótowo i z konieczności wybiórczo typologia filozofii Boga i filozofii religii ukazuje bogactwo ujęć. Relacje wzajemne układają się rozmaicie w zależności od koncepcji filozofii Boga i filozofii religii. W niektórych nie odróżnia się filozofii Boga i religii, inne z zasady negują odniesienie do metafizyki. Czy można oceniać, która z przedstawionych postaci interesujących nas dyscyplin jest bardziej wartościowa, a która mniej? Czy można wskazać na kryteria słusznego wyboru właściwej filozofii religii czy filozofii Boga?

Ocena zależy od zadań, jakie stawia się tym dyscyplinom. Czy są to cele tylko badawcze (odkrycie prawdy, nowe uporządkowanie, uzasadnienie) czy dydaktyczne (kształcenie w tej dziedzinie). Cele badawcze w filozofii także można traktować maksymalistycznie, jeśli szukamy wiedzy wyjaśniającej badaną rzeczywistość, czy minimalistycznie, kiedy chodzi nam o analityczno-krytyczny, źródłowy, wnikliwy i wszechstronny opis fenomenu religii ${ }^{6}$.

Bogactwo filozofii religii (i filozofii Boga), bogactwo różnorodnej wiedzy o religii jest czymś ogromnie cennym, jest rezultatem bogactwa samego fenomenu religijnego jak i życiowych zainteresowań i możliwości poznawczych człowieka. Żadnego typu wiedzy nie należy negować, ani też absolutyzować, żaden nie wyczerpuje wszystkich aspektów religii. Chodzi o to, by umieć spojrzeć szeroko, jakby „z góry” i zdawać sobie sprawę z charakteru epistemologicznego i metodologicznego poszczególnych typów wiedzy i religii, które zaspo-

${ }^{6}$ Por. S. K a mińs ski, Filozofia religii a filozofia Boga, „Roczniki Filozoficzne” 30 : 1982 z. 2 s. $15-21$. 
kajają potrzeby ludzkie wyrosłe $\mathrm{z}$ bycia człowieka w świecie, $\mathrm{z}$ bycia we współczesnej kulturze.

Współczesna sytuacja kulturowa w świecie i w Polsce domaga się jak najpełniejszej i najgłębszej wiedzy o religii i tej, którą może dostarczyć fenomenologia i takiej, która podejmuje problemy istnienia Boga, a ta związana jest $\mathrm{z}$ metafizyką i filozofią Boga. Uzupełnia ona lukę istotną w opisowej i interpretacyjnej wiedzy o religii, zwłaszcza przez jasne postawienie problemu istnienia Boga.

\section{FILOZOFIA RELIGII I FILOZOFIA BOGA W NURCIE FILOZOFII KLASYCZNEJ}

Sprecyzowanie, czym jest filozofia religii i filozofia Boga w klasycznym sposobie filozofowania, domaga się przypomnienia charakteru tej filozofii ${ }^{7}$.

Filozofia w sensie klasycznym ma za przedmiot wszystko, co istnieje, całą rzeczywistość. Ujmuje ją z punktu widzenia istnienia, jego sposobów, docieka właściwości, przysługujących wszystkim bytom, praw rządzących całą rzeczywistością. Stawia sobie cele maksymalistyczne. Dąży do poznania i wyjaśnienia badanej rzeczywistości przez wskazania na ostateczne czynniki ontyczne. Jest swoistym typem poznania i wiedzy, opiera się na własnym doświadczeniu, niezależnym od nauk i wiary religijnej.

Podstawową dyscypliną jest metafizyka, czyli ogólna teoria bytu. Sukcesywnie badając poszczególne dziedziny rzeczywistości powstają inne dyscypliny, antropologia filozoficzna, filozofia przyrody, etyka, filozofia kultury, religii, prawa, itp. Poszczególne dyscypliny filozofii są autonomiczne w tym sensie, że posiadają własny punkt wyjścia, własne doświadczenie. Wspólna jest natomiast metoda.

Podstawową dyscypliną jest metafizyka, która ma za zadanie poznać zasady (prawa) bytowania, fundamentalne właściwości wspólne (właściwości transcendentalne), wskazuje na czynniki konieczne wewnętrzne i zewnętrzne wszystkiego, co istnieje. Poznanie ma charakter transcendentalny — to znaczy nie zacieśnia się do jakiejś dziedziny rzeczywistości, jest otwarte na to, co jest i co może być. Ma także charakter analogiczny, poznając wspólne struktury, uznaje się, że każdy byt ma swój niepowtarzalny charakter.

Problem istnienia Absolutu (Boga) i jego natury pojawia się już w metafizyce. Byty dane w doświadczeniu w analizie okazują się złożone, zmienne, niesamowystarczalne bytowo. W wyjaśnieniu domagają się przyjęcia istnienia ich ostatecznego źródła, modelu i celu. Afirmacja Absolutu jest więc odpowiedzią na główne pytanie metafizyczne: dzięki czemu istnieje coś, co istnieć nie musi?

${ }^{7}$ Metodologiczne i merytoryczne rozwinięcie tego typu filozofii religii zawiera: Z. J. Z d y bi ck a, Człowiek i religia, Lublin 1987; Religia i religioznawstwo, Lublin 1988. 
Problem Absolutu pojawia się przy rozważaniu prawie wszystkich problemów w metafizyce. Teorią scalającą relacje bytów niekoniecznych z Absolutem jest teoria partycypacji jakby zwieńczająca całe poznanie metafizyczne. Ukazuje ona, że wszystko, co istnieje, istnieje na mocy uczestnictwa w istnieniu Boga, powiązane jest $\mathrm{z}$ Nim najgłębiej przez sam fakt istnienia, które jest istnieniem „w Nim” (,W nim istniejemy, poruszamy się i jesteśmy”). Bóg metafizyki nie jest Bogiem odległym, nie jest Bogiem statycznym - cała rzeczywistość jest w Nim. „Bliższy jest nam niż my sami sobie”. Bóg jest także modelem wszelkiego istnienia, zwłaszcza człowieka, który jest „stworzony na obraz i podobieństwo Boże", jest także Dobrem najwyższym, ku któremu wszystko zmierza. Mówiąc językiem metafizyki Bóg w stosunku do świata jest przyczyną sprawczą (źródłem istnienia), wzorczą (modelem) oraz celową, czyli Najwyższym Dobrem, z którym zjednoczenie jest warunkiem spełnienia się człowieka.

Uprawiana w ramach filozofii klasycznej filozofia Boga nie stanowi metodologicznie całkowicie odrębnej dyscypliny, nie ma bowiem odrębnych od metafizyki danych do wyjaśnienia (Bóg nie jest dany w punkcie wyjścia, nie jest przedmiotem bezpośredniego poznania). Jest zespołem twierdzeń wybranych $\mathrm{z}$ metafizyki, które wprost odnoszą się do istnienia Boga, ich rozwinięciem, często dopełniona fragmentami antropologii, etyki, czy nawet refleksji nad teoriami naukowymi.

Natomiast filozofia religii stanowi dyscyplinę odrębnąiw stosunku do metafizyki, i w stosunku do filozofii Boga, choć w ostatnim etapie wyjaśniania z nimi powiązaną. Ma własny punkt wyjścia. Jest nim dany w doświadczeniu wewnętrznym i zewnętrznym fakt religii. Zmierza do ujęcia jego istoty, stawia pytania, czym religia jest, jakie pełni funkcje w życiu ludzkim indywidualnym i w ludzkiej kulturze, dzięki czemu ostatecznie istnieje, jakie są jej ontyczne podstawy.

Można wyróżnić trzy etapy dociekań:

1) Stwierdzenie istnienia wielu faktów religijnych, które dane są człowiekowi w doświadczeniu wewnętrznym (jeśli jest człowiekiem religijnym) i w doświadczeniu zewnętrznym (obserwacja faktów religijnych).

2) Analiza danych doświadczenia, która ujawnia wielkie bogactwo religijnych aktów i przeżyć, ich złożoność. Są to akty psychiczne (poznawsze, dążeniowe, emocjonalne), fakty społeczne a także ontyczne. W nagromadzonym materiale empirycznym ujmuje się to, co konieczne, wspólne. W aktach religijnych człowiek ujmuje siebie i przeżywa siebie jako powiązanego z Transcendensem (Bogiem, bóstwem). Wszelka religia stanowi odniesienie, skierowanie człowieka do Transcendensu, które wyraża się w specjalnym zachowaniu człowieka, w działaniu. Relacja - człowiek - Transcendens ma więc charakter powinnościowy, jest dynamiczna, wyraża się w praxis religijnej, czyli 
odpowiednim działaniu, zwłaszcza modlitwie i kulcie, ofierze, określonej moralności.

3) Wyjaśnienie - skoro analiza ujawniła religię jako relację swoistą człowieka do Transcendensu, to dla bliższego poznania i wyjaśnienia charakteru relacji trzeba określić jej podmiot (człowieka), jej przedmiot - kres (transcendens) oraz jej podstawy — dlaczego zachodzi? Inaczej mówiąc — stawiamy zasadnicze pytanie, dlaczego takie zjawisko jak religia w ogóle istnieje. Chodzi o podmiotowe (ze strony człowieka) jak i przedmiotowe (transcendens) uzasadnienie faktu zachodzenia relacji religijnej. Jakie są racje ze strony człowieka oraz - czy przedmiot odniesienia religijnego — istnieje i w jaki sposób istnieje? Czy tylko w świadomości religijnej, jak to z modą podkreślali współcześni przeciwnicy religii, poczynając od Feuerbacha, czy istnieje niezależnie od ludzkiej indywidualnej i społecznej świadomości?

W wyjaśnianiu podstaw (źródeł) religii w człowieku odwołujemy się do doświadczenia ludzkiego, które w formie zalążkowej dane jest każdemu myślącemu człowiekowi, poznania swojej sytuacji egzystencjalnej. Człowiek, na każdym poziomie kultury, zdolny jest uświadomić sobie swoją sytuację egzystencjalną, poznać otaczający go świat, siebie w świecie, siebie jako podmiot i sprawcę swoich działań: poznania, miłości, decyzji. Doświadczenie swojej sytuacji egzystencjalnej ujawnia ograniczoność w istnieniu (czasowość, zmienności, niekonieczność), równocześnie dynamizm i możliwości, którymi człowiek transcenduje swoje ograniczenia - poznanie, miłość, wolność. Doświadcza potrzeby umocnienia w bytowaniu i dążeniu do pełni.

W tego typu doświadczeniu, które można rozbudowywać, i które stanowi podstawę filozoficznego poznania w metafizyce, ujawnia się otwartość człowieka na inne byty osobowe, a także na Byt Mocny, na Transcendens. Tu pojawia się myśl o Bogu, rodzi się idea Boga.

W opracowaniu tego podstawowego doświadczenia ludzkiego, które ujawnia otwartość osoby ludzkiej na Transcendens, ujawnia powiązanie człowieka z Bogiem, rozumianym w religii jako źródło życia, jego sensu i kres, spełnienie ludzkich działań, posługujemy się analizami, pojęciami, prawami wypracowanymi w metafizyce i antropologii filozoficznej. Skoro w antropologii filozoficznej człowiek ukazuje się jako osoba otwarta na drugie ty i analiza ludzkiego poznania i ludzkiej miłości okazuje otwarcie osoby ludzkiej na Ty absolutne, a w metafizyce przyjmuje się istnienie Boga, jako koniecznej przyczyny istnienia wszystkich bytów, wskazuje to na podmiotowe i przedmiotowe uzasadnienie faktu religii. Dzięki temu możemy powiedzieć, że religia jest istotnie powiązana z człowiekiem i ostatecznie wyjaśnia się bytową strukturą i egzystencjalną sytuacją osoby ludzkiej, która będąc przygodna, transcenduje ku wartościom absolutnym - prawdzie, dobru, pięknu i świętości. Powiązanie człowieka z Bogiem najpełniej wyjaśnia fakt partycypacji, ukazujący najściślejsze powiązanie wszystkiego z Bogiem, bo człowiek jako osoba zdolny jest poznać 
i w sposób ludzki, to znaczy świadomy i wolny nawiązać kontakt z Bogiem i to jest właśnie religia ${ }^{8}$.

W ostatniej fazie filozofii religii, to znaczy w fazie wyjaśniania, kiedy wskazuje się na ontyczne czynniki podmiotowe i przedmiotowe religii, odwołujemy się do metafizyki (filozofii Boga) oraz do antropologii filozoficznej. Inna jest jednak perspektywa poznawcza filozofii religii niż metafizyki. Filozofia religii posługuje się pojęciem bytu wymodelowanym na osobie, a nie ogólnym i transcendentalnym pojęciem bytu właściwym metafizyce. Byt osobowy jest nam poznawczo dostępny bezpośrednio przez nasze ludzkie przeżycia. Teoretycznie opracowywany w antropologii filozoficznej jako podmiot aktów świadomych i wolnych, staje się podstawą do sformułowania pojęcia Osobowego Absolutu (Boga), ku któremu zmierza osoba ludzka w wewnętrznym dialogu, pojmując Go jako Ty osobowe.

Człowiek jest więc jako osoba w swoim istnieniu i działaniu powiązany istotnie z Bogiem, jest homo religiosus. Religia nie jest jakąś jedną z dziedzin życia ludzkiego, jest sposobem istnienia człowieka. Poszczególne religie historyczne ujawniają w pełni to, co w teorii religii jest zarysowane. Pełne życie osobowe człowieka przebiega w perspektywie Boga, z Nim, w Nim, w postawie wiary, nadziei i miłości.

Człowiek przez realne życie religijne umacnia i rozwija siebie, oczywiście nie przez teorie o religii, ale przez fakty—czyny, z których najważniejsze stanowi modlitwa (dialog z Bogiem), ofiara (symbol daru z siebie, istoty wszelkiej miłości) oraz postępowanie ogarniające całe życie (moralność).

PHILOSOPHY OF RELIGION VS. PHILOSOPHY OF GOD AND METAPHYSICS

Sum mary

In order to describe the existing philosophical knowledge about God and religion the author examines present-day speculations on religion. At the outset she analyzes a variety of approaches to philosophy of God and philosophy of religion, and devides them into two tendencies of practising and lecturing on philosophy of God: (1) philosophy of God closely related to metaphysics, (2) philosophy of God as independent of metaphysics. On the other hand, philosophy of religion can be: (1) descriptive, (2) interpretatory, and (3) explanatory.

The author notices that the variety of philosophy of God and philosophy of religion results from richness of the religious phenomenon itself and life interests as well as the cognitive capacity of man.

${ }^{8}$ Rozwinięcie zagadnienia partycypacji zob.: Z. J. Zdy bick a, Partycypacja bytu. Próba wyjaśnienia relacji między światem a Bogiem, Lublin 1972. 
The second part of the article explores philosophy of God and philosophy of religion on the background of classical philosophy which separates philosophy of religion from metaphysics and philosophy of God. Philosophy of religion, however, refers to philosophical anthropology and metaphysics in order to show the subjective and objective ontological factors of religion.

The author reaches a conclusion that an authentic religious life grows not from theories on religion but from facts-acts, especially prayer, sacrifice and morality. 